\title{
Persepsi Penggemar Pasangan Boys Love (BL Ship) terhadap Homoseksualitas
}

\author{
Sintya Frank Sianturi, Ahmad Junaidi \\ sintya.915170124@stu.untar.ac.id,ahmadd@fikom.untar.ac.id \\ Fakultas Ilmu Komunikasi Universitas Tarumanagara
}

\begin{abstract}
These past few years, Thailand's entertainment industry has been increasing their production of Boys' Love series and movies. The genre blew up in 2014, and until 2020, around 57 BL series had been produced and released. This has led to the phenomenon of the escalation of the number of Thai BL fans in Indonesia. The aim of this research was to find out how BL Ship's fans or shippers perceive homosexuality. Perception is a meaning making activity of a sensory stimulus through gathering and interpreting process of information or message. To elaborate it, this research used the qualitative research method with case studies approach towards the members of BL ship Off Jumpol-Gun Atthaphan's fans kingdom. Data was gathered by interview, observation, and documentation. To analyze it, researcher conducted Glaser and Strauss's constant comparative method, and Mahpur's coding steps. The results showed that shippers' perception of homosexuality more or less got affected by what they consumed through media, such as BL series and ships. Along the way, their cultural background, religious views, personal experiences and values also influenced their views of the meaning of homosexuality. Researcher suggest that the professionals who are working in the industry of this genre to be mindful and take extra care since it's going to affect the audience's perception.
\end{abstract}

Keywords: boys' love, fans kingdom, homosexuality, perception

\begin{abstract}
Abstrak
Beberapa tahun terakhir, industri hiburan Thailand semakin gencar memproduksi drama serial dan film romantis bergenre Boys' Love (BL). Sejak pertama kali meledak tahun 2014 hingga 2020, terdapat setidaknya 57 serial drama BL yang telah dibuat dan ditayangkan. Hal ini menyebabkan fenomena peningkatan penggemar pasangan Thai Boys' Love (BL Ship) di Indonesia. Penelitian ini bertujuan untuk melihat bagaimana persepsi penggemar BL Ship terhadap homoseksualitas. Persepsi merupakan kegiatan pemberian makna pada stimulus sensorik yang diperoleh melalui proses menyimpulkan dan menafsirkan informasi dan atau pesan. Metode yang digunakan adalah metode penelitian kualitatif dengan pendekatan studi kasus. Subjek dalam penelitian ini adalah anggota kelompok penggemar pasangan BL Off Jumpol-Gun Atthaphan. Teknik pengumpulan data yang digunakan adalah teknik wawancara, observasi, dan dokumentasi. Data yang telah terkumpul kemudian direduksi, dikategorisasi, disintesisasi, dan kemudian ditarik kesimpulannya. Hasil penelitian menunjukkan bahwa terdapat faktor personal dan situasional yang mempengaruhi persepsi individu terhadap homoseksualitas. Latar belakang budaya, kepercayaan secara religius, dan nilai-nilai dari sekitar maupun pribadi individu turut mengambil peran dalam proses pembentukan persepsi individu atas homoseksualitas. Penting bagi pegiat genre ini untuk memerhatikan apa yang diproduksi karena apa yang ditampilkan akan mempengaruhi persepsi yang diterpanya.
\end{abstract}

Kata Kunci: boys' love, fans kingdom, homoseksualitas, persepsi 
Sintya Frank Sianturi, Ahmad Junaidi: Persepsi Penggemar Boys Love (BL Ship) terhadap Homoseksulitas

\section{Pendahuluan}

Beberapa tahun terakhir, industri hiburan Thailand mulai meningkatkan jumlah produksi karya bergenre Boys' Love $(B L)$. Dalam salah satu artikel keluaran Vice.com, Natthanai Prassanam, profesor sastra asal Universitas Kasetsart Bangkok, menyebutkan bahwa genre tersebut telah meledak di Thailand sejak tahun 2014. Kesuksesan Love Sick: The Series, mendorong perusahaan lain untuk ikut memproduksi lebih banyak tayangan bertema serupa (de Guzman, 2020). Menurut berita yang dilansir Asiaone.com, sejak tahun 2014 hingga 2020, terdapat setidaknya 57 serial drama bergenre BL yang diproduksi dan dirilis di Thailand. Layanan streaming gratis, LINE TV, menyebutkan bahwa jumlah audience share telah meningkat dari 5\% menjadi 34\% sejak tahun 2019 (Nugroho, 2020).

Menurut Welker (dalam McLelland, 2015), BL merupakan sebutan yang digunakan untuk menggambarkan genre yang berfokus pada kisah romantis sesama lelaki. Dari begitu banyaknya pasangan BL yang lahir dari serial Thai BL, pasangan Jumpol Adulkittiporn (จุมพล อดุลกิตติพร) atau Off dan Atthaphan Phunsawat (อรรถพันธ์ พูลสวัสดิ์) atau Gun (selanjutnya disebut Off-Gun) telah menjadi 'fenomena besar' bahkan sampai ke tanah air. Hal ini dapat dilihat dari tanda pagar (tagar/hashtag) yang berkaitan dengan keduanya kerap kali memasuki daftar trending topic lokal pada platform Twitter.

Di Indonesia, persepsi masyarakat terhadap homoseksual dapat dilihat dari gambaran umum hak-hak yang dimiliki kelompok Lesbian, Gay, Bisexual, dan Transgender (seterusnya disingkat LGBT) di nusantara. Berdasarkan laporan keluaran USAID dan UNDP yang bertajuk 'Laporan Nasional Indonesia: Hidup sebagai LGBT di Asia', hak asasi yang dimiliki kelompok LGBT di tanah air sangatlah minim. Hukum nasional dalam arti luasnya tidak menyediakan dukungan kepada kelompok LGBT meskipun homoseksualitas tidaklah ditetapkan sebagai bentuk tindak pidana. Tidak ada undang-undang yang secara tegas memayungi antidiskriminasi berkenaan dengan orientasi seksual ataupun berbasis identitas gender. Norma-norma agama dan kesusilaan yang dianut masyarakat pun juga bertentangan dengan homoseksualitas (UNDP; USAID, 2014).

Hal ini menarik perhatian peneliti karena meskipun memiliki latar belakang budaya dan sosial yang memandang negatif homoseksualitas, jumlah penggemar genre BL di nusantara tidaklah sedikit. Berangkat dari hal tersebut, penulis melakukan penelitian dengan mengangkat bagaimana persepsi penggemar pasangan Boys' Love (BL Ship) terhadap homoseksualitas sebagai rumusan masalah, dengan tujuan untuk mengetahui persepsi penggemar BL Ship mengenai homoseksualitas. Adapun konsep dan teori yang peneliti gunakan sebagai acuan dalam penelitian ini adalah sebagai berikut:

\section{Budaya Populer dan Boys' Love}

Adorno (dalam Burton, 2008) menerangkan bahwa pada era produk massa, budaya merupakan benda yang diproduksi atau paling tidak menggunakan produkproduk hasil produksi. Konsep ini menempatkan produk-produk budaya sebagai komoditas dan budaya populer merupakan produk budaya yang penuh akan berbagai komoditas.

Boys' Love (disingkat BL) merupakan sebutan yang digunakan untuk menggambarkan genre yang berfokus pada kisah romantis sesama lelaki (Welker dalam McLelland, 2015). Dalam sejarah perkembangannya, BL disebut sebagai 
budaya populer Jepang karena diduga berasal dari majalah IMAGE asal negara itu, yang meluncurkan slogan "Boys Love Comic" pada tahun 1991. Namun, banyak yang berpendapat bahwa nama genre 'Boys' Love' adalah terjemahan untuk shöunenai dalam bahasa Inggris yang berarti 'cinta antar laki-laki'. Sebelum itu, BL juga dikenal sebagai 'yaoi' yang merupakan singkatan dari tiga frasa yaitu「ヤマなし,オチ なし，意味なし」'yama nashi, ochi nashi, imi nashi' yang memiliki arti: “tiada klimaks, tiada penyelesaian, tiada makna" (Winduwati, 2013). Meski keduanya sering dianggap sama, cerita yaoi lebih cenderung menekankan pada elemen seksual atau erotik dan kurang berfokus pada alur cerita bila dibandingkan dengan shōunenai (Welker dalam McLelland, 2015; Futekiya, 2020).

\section{Fandom}

Fandom atau fans kingdom, menurut Baym (dalam McCudden, 2011) adalah sekumpulan orang yang terorganisir secara sosial dalam 'ruang' kesamaan apresiasi mereka atas sebuah objek budaya populer, atau hal lainnya. Objek yang dimaksud mempunyai arti yang luas, dapat berupa musik, siaran televisi, film, karya sastra, olahraga, dan masih banyak lagi. Dalam praktiknya, penggemar tidak hanya menjadi konsumen atau penikmat budaya pop, tetapi juga berperan aktif membangun makna dari apa yang ia konsumsi. McCudden (2011) mengemukakan bahwa studi mengenai penggemar, dewasa ini menunjukkan bahwa penggemar secara aktif melakukan meaning making atau aktivitas membuat makna dengan mengambil pesan dari media untuk memilah ataupun mengambilnya secara penuh ke dalam pengalaman dan perasaan mereka.

Selanjutnya, Bacon-Smith dan Jenkins (dalam McCudden, 2011) menyebutkan bahwa sebelum adanya komputer, kelompok komunitas penggemar berkomunikasi dengan bertatap muka atau lewat tulisan tangan dan terbentuk melalui pertemuan fans-club. Dengan masuknya internet, sesama penggemar dapat berhubungan satu sama lain dengan mudah dan bertukar topik serta ketertarikan tanpa penghalang jarak geografis. McHarry dan Pagliossotti (2010) menambahkan bahwa melalui internet, pembuat karya ataupun pengonsumsi (penggemar) mampu secara diam-diam membagikan, mempopulerkan, dan menikmati BL.

\section{Shipping}

Dalam budaya penggemar, shipping secara umum dikenal sebagai kegiatan menempatkan dua karakter atau tokoh fiksi dalam suatu hubungan yang bersifat romantis. Kata "ship" dalam "shipping" berasal dari "relationship" yang berarti hubungan. Individu yang dipasangkan pun kerap kali tidak terbatas pada tokoh fiksi, melainkan juga selebritis (Kircher dalam Rahmawati dkk., 2020).

Ketika membahas budaya pop BL, shipper sering disama artikan dengan 'fujoshi'. Menurut Galbraith (2011), fujoshi merupakan istilah dalam bahasa Jepang yang digunakan untuk mendefinisikan penggemar wanita yang menyukai visualisasi hubungan antar sesama jenis. Sugiura (dalam Ayudyasari, 2016) menerangkan bahwa sebenarnya fujoshi「腐女子」bila diterjemahkan memiliki arti "wanita busuk." Sebutan ini merupakan kritik kepada mereka yang berimajinasi tentang hubungan seks homoseksual yang tidak produktif karena secara biologis tidak menghasilkan anak. 
Sintya Frank Sianturi, Ahmad Junaidi: Persepsi Penggemar Boys Love (BL Ship) terhadap Homoseksulitas

\section{Persepsi}

Persepsi, atau dalam bahasa Inggris "perception" secara etimologis berasal dari bahasa latin, "percipere" yang berarti pemahaman atau pengertian. Menurut Rakhmat (2011), persepsi merupakan kegiatan memberikan makna kepada stimulus sensorik; pengalaman mengenai objek, peristiwa, atau hubungan lain yang didapat melalui proses menyimpulkan dan menafsirkan informasi dan atau pesan. Persepsi mempengaruhi stimulus atau pesan apa yang diserap individu dan makna apa yang mereka berikan saat mencapai kesadaran. Menurut DeVito (2011), terdapat tiga tahap proses persepsi, yaitu: tahap stimulasi alat indera, tahap pengurutan stimulasi alat indera, dan tahap penafsiran dan pengevaluasian stimulisasi alat indera

Dalam prosesnya pembentukannya, persepsi individu ditentukan oleh dua faktor, yaitu: faktor personal dan faktor situasional. Faktor personal atau faktor fungsional berasal dari kebutuhan, pengalaman, dan hal-hal personal lainnya. Dalam kata lain, yang mempengaruhi persepsi bukanlah stimulus, melainkan karakteristik individu yang menerimanya. Kebutuhan, kesiapan mental, suasana emosional, dan latar belakang budaya mempengaruhi cara mempersepsikan sesuatu. Berbeda dengan faktor situasional atau struktural yang mana menunjukkan manusia memandang stimulus dalam konteksnya atau dalam strukturnya. Sederhananya, bila ingin memahami seorang individu, ia perlu dilihat dalam konteksnya, lingkungannya, dan masalah yang ia hadapi (Krech dan Crutchfield dalam Rakhmat, 2011)

Selain kedua faktor tersebut, terdapat aspek perhatian yang mempengaruhi persepsi. Andersen (dalam Rakhmat, 2011) menjelaskan bahwa perhatian merupakan proses mental saat salah satu stimulus menguat ketika stimulus lainnya melemah dalam kesadaran individu. Terdapat dua faktor yang mempengaruhi perhatian, yaitu: faktor eksternal penarik perhatian dan faktor internal penaruh perhatian. Faktor eksternal menjelaskan bagaimana stimulus diperhatikan karena mempunyai sifat yang menonjol seperti gerakan, intensitas stimuli, kebaruan, dan pengulangan. Berbeda dengan faktor internal yang mengacu pada bagaimana individu memiliki perhatian yang selektif. Hal ini disebabkan oleh faktor biologis dan faktor sosiopsikologis yang dimiliki individu berbeda-beda.

\section{Homoseksualitas}

Homoseksualitas secara etimologis berasal dari bahasa Yunani, "homo" yang berarti sama dan "sexual" yang memiliki makna berhubungan dengan naluri, proses psikologi, dan aktivitas yang berhubungan dengan atraksi atau hubungan intim fisik antara individu. Menurut kamus Oxford (2003), "homosexual; homosexuality" berarti "(individu) berketertarikan kepada individu lain dengan jenis kelamin yang sama." Sementara itu, American Psychological Association atau APA (dalam "Definitions Related to Sexual Orientation and Gender Diversity in APA Document," 2015) mendefinisikan homoseksualitas sebagai atraksi romantis, atraksi seksual, atau tingkah laku seksual antara sesama jenis kelamin atau gender. Gay adalah sebutan untuk pria homoseks dan lesbian untuk wanita homoseks.

\section{Metode Penelitian}

Penelitian ini menggunakan metode penelitian kualitatif dengan pendekatan studi kasus terhadap kelompok penggemar BL ship Off-Gun. Penelitian kasus (case studies) adalah proses mengumpulkan data dan informasi dengan mendalam, detail, intensif, holistik, dan sistematik mengenai individu, kejadian, latar sosial, ataupun 
kelompok dengan memanfaatkan beragam metode juga teknik dan berbagai sumber informasi guna memahami dengan efektif bagaimana individu, kejadian, atau latar sosial itu beroperasi sesuai pada konteksnya (Yusuf, 2014). Hal ini sesuai dengan apa yang dibutuhkan peneliti untuk mengetahui jawaban dari rumusan masalah penelitian ini yang spesifik pada kasus khusus yakni persepsi dari penggemar pasangan BL terhadap homoseksualitas.

Dalam penelitian ini, metode yang digunakan untuk mengumpulkan data adalah wawancara, observasi, dan dokumentasi. Sementara teknik menganalisis data yang dipakai adalah metode perbandingan tetap Glaser \& Strauss. Secara umum, proses metode ini terdiri dari: reduksi data, kategorisasi dan sintesisasi data secara menyeluruh, kemudian hipotesis kerja disusun dengan merumuskan suatu pernyataan yang merupakan teori substantif (berasal dan masih berkaitan dengan data) yang sekiranya menjawab pertanyaan penelitian (Moleong, 2017). Objek dari penelitian ini adalah pemikiran dari subjek penelitian, yaitu kelompok penggemar BL ship OffGun.

Peneliti menarik kesimpulan secara deskriptif berdasarkan data primer yang diperoleh yaitu pernyataan informan yang berjumlah empat orang, dan data sekunder yang diperoleh dari hasil observasi dan dokumentasi cuitan akun Twitter informan. Informan merupakan anggota kelompok Babii Indonesia (penggemar BL ship OffGun) yang dipilih dengan metode purposive sampling, atau metode yang mana sumber informasi dipilih berdasarkan tujuan atau pertimbangan tertentu. Keempat narasumber merupakan admin dari fanbase Babii Indonesia pada platform Twitter, dan masing-masing berinisial atau bernama informan A, informan B, Olivia, dan Yulinda.

\section{Hasil Temuan dan Diskusi}

$B L$ ship Off-Gun merupakan sebutan untuk pasangan on-screen yang terdiri dari dua aktor pria yang bernama Jumpol Adulkittiporn (จุมพล อดุลกิตติพร) atau Off dan Atthaphan Phunsawat (อรรถพันธ์ พูลสวัสดิ์) atau Gun. Berdasarkan informasi dari situs resmi agensi keduanya, GMMTV, Off adalah pria berkelahiran 20 Januari 1991 dan merupakan lulusan dari Fakultas Teknik Informasi dan Komunikasi, Universitas Silpakorn. Sementara, Gun adalah aktor berkelahiran 4 Oktober 1993 yang tengah menjalani studinya sebagai mahasiswa Fakultas Ilmu Politik di Universitas Ramkhamhaeng. Pada saat penelitian ini dilakukan, keduanya telah bekerja sama dalam berbagai produk media sebagai pasangan on-screen. Mulai dari TV series, film komersil, hingga variety shows. Keduanya terkenal dengan peranan mereka sebagai pasangan dalam serial televisi Senior Secret Love: Puppy Honey, dan Theory of Love.

Selanjutnya, untuk memperoleh jawaban dari rumusuan masalah, penelitian ini menempatkan anggota komunitas Babii Indonesia yang merupakan sebutan untuk kelompok penggemar pasangan BL Off-Gun asal Indonesia sebagai subjek penelitian. Dalam penelitian ini dilibatkan empat orang narasumber sesuai dengan kriteria yang telah ditentukan peneliti. Penjabaran profil masing-masing informan yang telah diwawancarai dapat dilihat pada data berikut:

a. Informan A (nama dirahasiakan atas permintaan informan) adalah mahasiswi semester tujuh Jurusan Farmasi dari Fakultas Farmasi Universitas Halu Oleo. Lahir pada tanggal 21 Oktober 1999 dan beragama Islam. A merupakan admin 
Sintya Frank Sianturi, Ahmad Junaidi: Persepsi Penggemar Boys Love (BL Ship) terhadap Homoseksulitas

Twitter@Babiisid dan telah menjadi penggemar Off-Gun selama kurang lebih 11 bulan.

b. Informan B (nama dirahasiakan atas permintaan informan) adalah mahasiswi semester satu Jurusan Agribisnis dari Politeknik Negeri Banyuwangi. Lahir pada tanggal 1 Januari 2002 dan beragama Islam. B merupakan admin Twitter (a)Babiisid dan telah menjadi penggemar Off-Gun selama kurang lebih 2 tahun.

c. Informan C (Olivia) adalah mahasiswi semester lima Jurusan Business Administration dari Business Faculty of Tamkang University. Lahir pada tanggal 23 April 2000 dan beragama Katolik. Olivia merupakan admin Twitter (a)Babiisid dan telah menjadi penggemar Off-Gun selama kurang lebih 7 bulan.

d. Informan D (Yulinda) adalah mahasiswi semester tiga Jurusan Ilmu Komunikasi dari Fakultas Ilmu Komunikasi Universitas Gunadarma. Lahir pada tanggal 12 Juni 2001 dan beragama Islam. Yulinda merupakan admin Twitter@Offgunfess dan telah menjadi penggemar Off-Gun selama kurang lebih 3 tahun.

Temuan dalam penelitian ini diolah dan dianalisis secara manual menggunakan perangkat lunak Microsoft Excel sebagai media pengurutan dan pemberian kode berdasarkan kategori dan sub kategori dari transkrip wawancara informan. Selanjutnya, hasil temuan dituangkan ke dalam tabel keranjang data mengikuti panduan koding Mahmur (2017) untuk mempermudah peneliti mencari persamaan dan perbedaan dari pernyataan masing-masing informan. Adapun paparan hasil temuan secara singkat akan disajikan dalam tabel berikut:

Tabel 1. Persepsi terhadap Homoseksualitas

\begin{tabular}{|c|c|c|c|c|c|}
\hline \multirow{2}{*}{ No } & \multirow{2}{*}{ Persepsi } & \multicolumn{4}{|c|}{ Informan } \\
\hline & & A & $\mathrm{B}$ & $\mathrm{C}$ & $\mathrm{D}$ \\
\hline 1. & $\begin{array}{l}\text { Homoseksualitas adalah ketertarikan emosional terhadap } \\
\text { individu berjenis kelamin sama }\end{array}$ & $\sqrt{ }$ & & & $\sqrt{ }$ \\
\hline 2. & $\begin{array}{l}\text { Homoseksualitas adalah ketertarikan seksual terhadap individu } \\
\text { berjenis kelamin sama }\end{array}$ & $\sqrt{ }$ & $\sqrt{ }$ & $\sqrt{ }$ & \\
\hline 3. & $\begin{array}{l}\text { Homoseksualitas mengacu pada hubungan homoseks antara laki- } \\
\text { laki dengan laki-laki }\end{array}$ & $\sqrt{ }$ & $\sqrt{ }$ & $\sqrt{ }$ & $\sqrt{ }$ \\
\hline 4. & $\begin{array}{l}\text { Homoseksualitas mengacu pada hubungan homoseks antara } \\
\text { perempuan dengan perempuan }\end{array}$ & $\sqrt{ }$ & $\sqrt{ }$ & $\sqrt{ }$ & \\
\hline 5. & $\begin{array}{l}\text { Homoseksualitas bukanlah hal yang dapat diceritakan secara } \\
\text { bebas ke siapa saja }\end{array}$ & $\sqrt{ }$ & $\sqrt{ }$ & $\sqrt{ }$ & $\sqrt{ }$ \\
\hline 6. & $\begin{array}{l}\text { Homoseksualitas bukanlah sesuatu yang harus dipandang } \\
\text { berbeda atau keluar dari moral }\end{array}$ & $\sqrt{ }$ & $\sqrt{ }$ & $\sqrt{ }$ & $\sqrt{ }$ \\
\hline 7. & Homoseksualitas bertentangan dengan agama & $\sqrt{ }$ & $\sqrt{ }$ & $\sqrt{ }$ & $\sqrt{ }$ \\
\hline 8. & Homoseksualitas tidak sesuai dengan norma & $\sqrt{ }$ & $\sqrt{ }$ & $\sqrt{ }$ & $\sqrt{ }$ \\
\hline 9. & $\begin{array}{l}\text { Individu homoseksual menghadapi permasalahan yang rumit dan } \\
\text { menerima perlakuan yang tidak baik dari lingkungan }\end{array}$ & $\sqrt{ }$ & $\sqrt{ }$ & $\sqrt{ }$ & $\sqrt{ }$ \\
\hline 10 . & $\begin{array}{l}\text { Perbedaan homoseksualitas dan heteroseksualitas hanya terdapat } \\
\text { pada perbedaan preferensi gender }\end{array}$ & $\sqrt{ }$ & $\sqrt{ }$ & $\sqrt{ }$ & $\sqrt{ }$ \\
\hline
\end{tabular}

Sumber: Data Peneliti

BL merupakan bagian dari budaya populer asal Jepang yang kini sudah menjadi bagian dari industri hiburan berbagai negara. Salah satu negara penghasil serial drama BL adalah Thailand. Menurut Laporan UNDP dan USAID (2014), hal ini telah menjadi bagian dari agenda pariwisata negara Gajah Putih itu. Otoritas 
Pariwisata Thailand secara aktif menjual citra negara tersebut sebagai "Gay Paradise" atau surga homoseksual. Thai BL, dewasa ini tidak hanya populer di negara asalnya, tetapi ketenarannya juga telah mencapai berbagai negara di dunia, termasuk Indonesia.

Menurut Welker (dalam McLelland, 2015), BL merupakan sebutan yang digunakan untuk menggambarkan genre yang berfokus pada kisah romantis sesama lelaki. Sementara itu, persepsi merupakan kegiatan memberikan makna kepada stimulus sensorik. Rakhmat (2011) mendefinisikan persepsi sebagai pengalaman mengenai objek, peristiwa, atau hubungan lain yang didapat melalui proses menyimpulkan dan menafsirkan informasi dan atau pesan.

Sebelum terjadi proses persepsi. Terdapat suatu aspek yang disebut perhatian, yang menyebabkan stimulus tertentu tampak menonjol ketika stimulus lainnya melemah. Menurut Andersen (dalam Rakhmat, 2011), perhatian ini dipengaruhi oleh dua faktor, yaitu: faktor eksternal penarik perhatian dan faktor internal penaruh perhatian. Faktor eksternal menjelaskan bagaimana stimulus diperhatikan karena mempunyai sifat yang menonjol. Dalam kasus ini, faktor eksternal yang menarik perhatian penggemar pasangan BL untuk mengonsumsi tayangan BL adalah alur ceritanya yang tidak biasa, berbeda, dan memiliki konflik yang rumit. Sementara itu, terhadap pasangan BL Off-Gun sendiri, keempat informan berpendapat bahwa kemistri antara keduanya membuat mereka lebih menarik daripada pasangan BL lainnya.

Selain faktor eksternal, juga terdapat faktor internal penaruh perhatian. Faktor ini mengacu kepada bagaimana individu memiliki perhatian yang selektif. Hal tersebut disebabkan oleh faktor biologis dan faktor sosiopsikologis yang dimiliki individu berbeda-beda. Seperti misalnya informan A yang mengaku bahwa ia menggemari pasangan BL Off-Gun secara spesifik karena secara pribadi menyukai pasangan yang memiliki perbedaan tinggi badan mencolok dan merasa keduanya cocok.

Melalui tayangan $\mathrm{BL}$ yang dikonsumsinya, penggemar pasangan $\mathrm{BL}$ membentuk beberapa persepsi terhadap homoseksualitas pada benak mereka. Menurut McCudden (2011), aktivitas membuat makna dan interpretasi terhadap suatu pesan media ini dinamakan kegiatan meaning making. Informan yang merupakan seorang penggemar pasangan BL mengambil 'pesan' dari serial drama BL untuk kemudian memilah dan menerapkannya ke dalam pengalaman dan perasaan mereka hingga menghasilkan suatu persepsi atas apa yang dimaksud dengan homoseksualitas. Adapun dua persepsi terhadap homoseksualitas yang terbentuk dari alur cerita yang ditampilkan dalam BL dapat dilihat pada penjabaran berikut ini:

Persepsi pertama, homoseksualitas bukanlah sesuatu yang harus dipandang berbeda atau keluar dari normal. Meskipun memiliki latar belakang budaya dan keyakinan yang menentang homoseksualitas, masing-masing informan berpandangan bahwa setiap orang berhak memiliki ketertarikan kepada siapa pun tanpa batasan gender.

Kedua, persepsi bahwa individu homoseksual menghadapi permasalahan yang rumit dalam kehidupan mereka dan menerima perlakuan yang tidak baik dari lingkungan. Pandangan ini berangkat dari alur cerita BL yang kerap kali mengangkat pemasalahan tokohnya dari aspek penerimaan sosial. Persepsi ini juga menyebabkan penggemar BL meskipun tidak sepenuhnya mendukung homoseksualitas, tetap dapat merasakan simpati terhadap invididu penyuka sesama jenis. 
Di Indonesia, pandangan mengenai homoseksualitas cenderung ke arah negatif. Faktor nilai-nilai, norma setempat, dan pengaruh pandangan agama yang dianut tidak dapat dielakkan mempengaruhi cara pandang masyarakat tanah air terhadap homoseksualitas. Berangkat dari faktor personal berupa latar belakang budaya dan agama ini, informan memiliki tiga persepsi lainnya mengenai homoseksualitas, yaitu persepsi bahwa homoseksualitas merupakan hal yang bertentangan dengan agama, persepsi bahwa perilaku homoseksual merupakan sesuatu yang tidak normal atau tidak sesuai dengan norma, dan persepsi bahwa perilaku homoseksual adalah hal yang menjijikkan dan atau merupakan suatu 'penyakit'.

Homoseksualitas bukanlah hal yang dapat dengan mudah diterima masyarakat dan berdasarkan penelitian yang dilakukan, informan mengaku memiliki rasa takut untuk membagikan konten terkait pasangan BL di akun pribadi mereka. Mereka mempersepsikan hal-hal yang berhubungan dengan homoseksualitas sebagai sesuatu yang tidak dapat diceritakan secara bebas kepada siapa saja. Hal ini didorong atas faktor internal rekaman pengalaman pribadi akan respon dan atau reaksi negatif yang pernah diterima keempat informan dari sekitar mereka ketika membagikan konten atau hal-hal seputar BL pada akun pribadi dan di luar dunia maya.

Peneliti juga menemukan bahwa secara umum informan mempersepsikan homoseksualitas sebagai ketertarikan secara emosional dan atau seksual terhadap individu berjenis kelamin yang sama. Tiga dari empat informan mengaku bahwa definisi homoseksual mengacu kepada hubungan homoseks perempuan dan homoseks laki-laki. Sementara informan terakhir, Yulinda, berpendapat bahwa arti homoseksualitas lebih condong ke hubungan homoseks antar laki-laki karena ia jarang mendengar kasus homoseks perempuan. Terlihat bahwa faktor pengalaman mempengaruhi persepsi Yulinda terhadap makna kata homoseksualitas.

Persepsi umum lainnya adalah pandangan mengenai perbedaan homoseksualitas dengan heteroseksualitas yang hanya terdapat pada ketidaksamaan preferensi gender. Keempat informan sepakat bahwa pilihan ketertarikan akan jenis kelamin tertentu merupakan hak masing-masing individu. Mereka juga mengaku bersikap netral dan biasa saja terhadap homoseksualitas.

Dari penelitian ini, faktor personal atau fungsional yang terlihat jelas mempengaruhi individu dalam mempersepsikan homoseksualitas adalah latar belakang nilai-nilai budaya, agama, dan pengalaman individu. Sementara faktor situasional atau strukturalnya terdapat pada bagaimana informan melihat situasi yang dialami pelaku atau pasangan homoseksual. Penggemar BL mengaku mengetahui kesulitan yang dihadapi individu homoseksual dari tayangan BL yang mereka konsumsi. Faktor struktural ini menyebabkan keempat informan tidak bersikap menolak ataupun mencela kelompok homoseksual.

\section{Simpulan}

Berdasarkan hasil penelitian yang telah dilakukan, peneliti menemukan bahwa tayangan BL sedikit banyak mempengaruhi persepsi penggemar pasangan BL terhadap homoseksualitas. Faktor yang berasal dari dalam diri dan luar diri individu merupakan suatu kesatuan yang bersifat tumpang tindih, saling mempengaruhi bagaimana suatu stimulus menjadi objek perhatian, dan bagaimana seorang individu mempersepsikan sesuatu. 
Penggemar pasangan BL memandang homoseksualitas sebagai hubungan atau ketertarikan secara emosional dan seksual terhadap individu berjenis kelamin sama. Mereka beranggapan bahwa homoseksualitas adalah hal yang 'tabu', bertentangan dengan agama, tidak sesuai norma, dan sulit diterima secara sosial. Latar belakang budaya dan agama yang menentang perilaku homoseksual mempengaruhi persepsi individu terhadap homoseksualitas. Namun, hal itu tidak lantas membuat mereka berhenti menyukai serial BL ataupun mempercayai hubungan pasangan BL yang mereka gemari.

Menyenangi cerita atau pasangan BL bukan berarti penggemar mendukung sepenuhnya homoseksualitas. Terdapat pro-kontra yang berasal dari latar belakang budaya, agama yang dianut informan, serta pemikiran atau pendapat pribadi mereka yang merasa bahwa preferensi seksualitas merupakan hak setiap orang dan merupakan urusan dengan 'Tuhan' masing-masing.

\section{Ucapan Terima Kasih}

Penulis mengucapkan terima kasih kepada orang tua dan keluarga yang telah memberikan dukungan serta doa, admin-admin fanbase Off-Gun Indonesia yang telah bersedia menjadi informan penelitian, serta teman-teman yang telah menemani penulis dari awal penelitian hingga penulisan jurnal ini.

\section{Daftar Pustaka}

APA. (4 Oktober 2020). Definitions Related to Sexual Orientation and Gender Diversity 2015. Diakses dari https://www.apa.org/pi/lgbt/resources/sexualitydefinitions.pdf.

Ayudyasari, D. (2016). Konstruksi makna gay bagi penggemar manga Yaoi (fujoshi) pada anggota komunitas otaku di Pekanbaru. Jurnal Online Mahasiswa FISIP, 3(2), 1-15.

Burton, G. (2008). Pengantar untuk memahami media dan budaya populer. Yogyakarta: Jatasutra.

de Guzman, C. (2020, 17 Juni). Boys' love: The gay romance TV genre taking over Southeast Asia. Vice. https://www.vice.com/en/article/qj4k55/boys-love-tvasia-trend-lgbtq-2gether, diunduh tanggal 16 Januari 2021.

DeVito, J. A. (2011). Komunikasi antarmanusia (Edisi 5). Tangerang: Karisma Publishing Group.

Futekiya (2020, 8 Mei). What is Boys' Love? https://futekiya.com/what-is-boyslove/, diunduh tanggal 6 Oktober 2020.

Galbraith, P. W. (2011). 'Fujoshi: Fantasy play and transgressive intimacy among "rotten girls" in contemporary Japan'. Signs: Journal of Women in Culture and Society, 37(1), 211-232.

Levi, A., McHarry M., Pagliossotti, D. (2010). Boys' Love manga: Essays on the sexual ambiguity and cross-cultural fandom of genre. Jefferson, North Carolina: McFarland \& Company, Inc.

Mahpur, M. (2017). Memantapkan analisis data kualitatif melalui tahapan koding http://repository.uin-malang.ac.id/800, diunduh tanggal 26 November 2020

Moleong, L. J. (2017). Metodologi penelitian kualitatif (Edisi Revisi). Bandung: PT Remaja Rosdakarya. 
Sintya Frank Sianturi, Ahmad Junaidi: Persepsi Penggemar Boys Love (BL Ship) terhadap Homoseksulitas

McCudden, M. L. (2011). Degrees of fandom: Authenticity \& hierarchy in the age of media convergence. Disertasi. Lawrence: University of Kansas.

Nugroho, J. (2020, 11 Oktober). Thailand's erotic Boys' Love TV dramas are a hit with Indonesians both gay and straight. Asia One. https://www.asiaone.com/entertainment/thailand-s-erotic-boys-love-tvdramas-are-hit-indonesians-both-gay-and-straight, diunduh tanggal 16 Januari 2021.

Rahmawati, D., Anindhita, W., Decintya., Lusia, A., Wisesa, N. R. (2020). An ethnography of shipping as a communication practice within the fujoshi community in Indonesia. Dalam $3^{\text {rd }}$ International Conference on Vocational Higher Education (ICVHE 2018), 440-450. https://doi.org/10.2991/assehr.k.200331.178.

Rakhmat, J. (2011). Psikologi komunikasi (Edisi 2). Bandung: PT Remaja Rosdakarya.

UNDP, USAID. (2014). Being LGBT in Asia: Thailand country report. Bangkok.

UNDP, USAID. (2014). Hidup sebagai LGBT di Asia: Laporan nasional Indonesia. Jakarta.

University of Oxford. (2003). Oxford learner's pocket dictionary (3 ${ }^{\text {rd }}$ Edition). Oxford: Oxford University Press.

Welker, J. (2015). A brief history of Shonen'ai, Yaoi, and Boys Love. Dalam M. McLelland, K. Nagaike, K. Suganuma, \& J. Welker, Boys Love manga and beyond (42-75). Jackson: University Press of Mississippi.

Winduwati, S. (2013). Fujoshi remaja dan kenikmatan bermedia Yaoi (studi kasus pada remaja putri penggemar fiksi romantis homoerotis Jepang). Karya Ilmiah Dosen https://repository.untar.ac.id/426, diunduh tanggal 3 September 2020.

Yusuf, A. M. (2014). Metode penelitian kuantitatif, kualitatif, dan penelitian gabungan. Jakarta: Kencana. 